\title{
Bentuk Penyajian Tari Kreasi Ratoeh Jaroe di Sanggar Budaya Aceh Nusantara (Buana, Banda Aceh)
}

\author{
Riska Gebrina \\ Universitas Syiah Kuala Banda Aceh, Fkip Sendratasik \\ rizkageubrina19@gmail.com
}

\begin{abstract}
Abstrak
Penelitian ini bertujuan mendeskripsikan bentuk penyajian tari Ratoeh Jaroe di Sanggar Budaya Aceh Nusantara (BUANA) Banda Aceh. Sumber data dan lokasi dalam penelitian ini adalah ketua sanggar Budaya Aceh Nusantara (BUANA), koreografer atau penata tari, penari tari, dan penata musik tari Ratoeh Jaroe. Pendekatan yang digunakan dalam penelitian ini adalah kualitatif dan jenis penelitian deskriptif. Pengumpulan data dilakukan dengan teknik observasi, wawancara, dan dokumentasi. Teknik analisis data dalam penelitian ini yaitu mereduksi data, display, dan verifikasi. Hasil penelitian mengungkapkan ciri spesifik bentuk penyajian tari Ratoeh Jaroe pada sanggar Budaya Aceh Nusantara (BUANA) yang diciptakan oleh Khairul Anwar pada tahun 2008, serta judul tarian ini diciptakan oleh Khairul Anwar pada tahun 2011. Tari Ratoeh Jaroe ditarikan oleh sebelas penari wanita. Tari Ratoeh Jaroe memiliki tiga puluh tiga gerakan dan lima kali pengulangan gerak. Diiringi dengan alat musik tradisional Aceh seperti seurune kale, rapai, geundrang, dan darabbuka. Tata rias yang digunakan adalah rias korektif, serta tata busana yang disesuaikan dengan konsep tari Ratoeh Jaroe. Tari ini dipentaskan pada proscenium stage namun bisa juga di lapangan terbuka. Fungsi tari Ratoeh Jaroe sebagai salah satu media dakwah yang mencerminkan nilai-nilai kependidikan, keagamaan, sopan santun, kepahlawanan, kekompakan, dan kebersamaan yang diperlihatkan melalui gerakan jari tangan penari. Pada pentas tari Ratoeh Jaroe inilah penonton akan menangkap maksud karya yang ditampilkan.
\end{abstract}

Kata kunci: bentuk penyajian, tari, ratoeh jaroe
Abstract
This research purposed to decribe forming of presenting Ratoeh Jaroe dance at Sanggar Budaya Aceh Nusantara (BUANA) Banda Aceh. Data resources and location of the research are head of sanggar Budaya Aceh Nusantara (BUANA), choreography or dance stylist of Ratoeh Jaroe dance, dancers of Ratoeh Jaroe dance, and music stylist of Ratoeh Jaroe dance. The approaching used in this research is qualitative with descriptive research. Data collection used with observation technique, inteview and documentations. Technique analysis data in this research was data reduction, data display and verification. The result of the research shown that Ratoeh Jaroe dance at sanggar Budaya Aceh Nusantara (BUANA) created by Khairul Anwar in 2009 along with title of this dance created by Khairul Anwar in 2011. Ratoeh Jaroe dance danced by 11 female dancers, and the function Ratoeh Jaroe dance as one of da'wah media which is reflected educative, religious, politeness, heroic, harmony and togetherness that is shown by the movement of dancers' fingers. Ratoeh Jaroe dance has thirty three movements and eleven repeating movements. Accompanied by Aceh traditional 
music instruments like seurune kale, rapai, geundrang and darabbuka. Cosmetic used in this dance was beauty make up, and dressmaking which is adjusted by the concept of Ratoeh Jaroe dance. This dance performed at proscenium stage and performed at outdoor area as well, thus, in this stage Ratoeh Jaroe dance would be performing with the aim to make spectators at audiences understood the purpose of creation that performed.

Keywords: forming of presenting, dance, ratoeh jaroe

\section{Pendahuluan}

Aceh merupakan provinsi yang terletak di sebelah barat kepulauan Nusantara, yakni Pulau Sumatra. Agama, pendidikan, dan adat, membuat Aceh dikenal sebagai provinsi yang diberi penghargaan istimewa. Keistimewaan adat dan budaya Aceh terlihat jelas dalam bentuk seni budaya. Seni dan budaya merupakan dua hal yang tidak dapat dipisahkan dalam kehidupan masyarakat. Kebudayaan Aceh yang sangat terlihat adalah adat, karena adat terdapat dalam hidup kemasyarakatan, keagamaan, perekonomian, dan dalam berkesenian.

Seni adalah ungkapan perasaan dan pengalaman batin manusia yang dikomunikasikan melalui media tertentu yang bertujuan untuk mengungkapkan nilai-nilai kemanusiaan suatu kelompok masyarakat atau individu dalam memenuhi kebutuhan spiritualnya. Selain pernyataan di atas, seni juga sebagai hasil keindahan sehingga dapat menggerakkan perasaan indah orang yang melihatnya. Oleh karena itu, perbuatan manusia yang dapat mempengaruhi dapat menimbulkan perasaan yang indah juga. Salah satu cabang seni adalah seni tari.

Hermaliza (2011: 31) menyatakan bahwa "Tari tradisional adalah tari yang mengalami satuan perjalanan hidup yang cukup lama dan memiliki nilai-nilai masa lampau yang mempunyai hubungan ritual”. Tari tradisional juga merupakan bentuk tarian yang sudah lama ada dalam sekelompok masyarakat dan tari tradisional diwariskan secara turun-temurun dari generasi ke generasi, sedangkan tari kreasi baru adalah tari yang mengarah kepada kebebasan dalam pengungkapan, tidak berpijak pada pola tradisi itu lagi. Tari kreasi baru Aceh sangat erat kaitannya dengan kaidah syariah agama Islam, terciptanya tari kreasi baru/garapan baru biasanya pencipta tari diilhami oleh berbagai bentuk nilai tradisional yang telah disepakati, kesepakatan dari komunitas masyarakat tersebut tidak tertulis, baik itu ragam gerak, pola lantai, dan unsur-unsur koreografi lainnya masih kuat memegang akar tradisi Aceh, seperti halnya tari Ratoeh Jaroe.

Salah satu sanggar yang berperan aktif dalam proses pengembangan tari kreasi baru adalah Sanggar Budaya Aceh Nusantara (BUANA). Sanggar Budaya Aceh Nusantara (BUANA) terletak di Taman Budaya Banda Aceh yang dikoordinasikan oleh Khairul Anwar. Sanggar ini didirikan pada tanggal 19 Januari 1999. Sanggar Budaya Aceh Nusantara (BUANA) adalah salah satu wadah kreativitas muda mudi di bidang seni dan budaya Aceh, khususnya kesenian tradisional Aceh dan kreasi, salah satunya yaitu tari Ratoeh Jaroe. Tari Ratoeh Jaroe terdiri dari dua kata yang berasal dari bahasa Aceh yaitu Ratoeh yang artinya bercerita, dan Jaroe yang berarti jari. Dengan demikian, yang 
dimaksud dengan judul tarian ini adalah melantunkan syair atau menceritakan sebuah kisah dengan diiringi petikan-petikan jari tangan.

Tari Ratoeh Jaroe pada sanggar Budaya Aceh Nusantara (BUANA) diciptakan oleh Khairul Anwar pada tahun 2008. Tari Ratoeh Jaroe adalah tari kreasi yang berasal dari Aceh. Tari Ratoeh Jaroe biasanya disajikan dalam perayaaan adat namun, bisa juga disajikan sebagai media hiburan bagi masyarakat. Syair dalam tari Ratoeh Jaroe mengandung makna yang dalam sebagai khazanah kebudayaan Aceh. Latar belakang hadirnya tari Ratoeh Jaroe juga untuk membangkitkan kembali semangat masyarakat Aceh dari keterpurukan konflik/musibah yang terjadi di Aceh, serta menularkan nilai Islam dalam syair yang dibawakan.

Tari Ratoeh Jaroe sangat berkembang di seluruh Aceh maupun Indonesia. Setiap sanggar memiliki keunikan dan kekhasan masing-masing pada setiap geraknya, begitu juga pada sanggar Budaya Aceh Nusantara (BUANA). Berdasarkan observasi pada sanggar Budaya Aceh Nusantara (BUANA), tari ini memiliki keunikan dan kedinamisan pada musik, gerak, dan pola lantai pada setiap perubahan geraknya.

Keunikan dari musik adalah banyaknya alat musik tradisional yang dimainkan dan membuat suatu komposisi musik menjadi berkesinambungan dengan gerakan tarinya. Pada awal tari menggunakan seurune kale dan darabbuka saja, setelah itu dilanjutkan dengan pukulan rapai dan geundrang. Keunikan yang ditampilkan pada gerak adalah pada tari ini memiliki gerak-gerak yang tegas, yang melambangkan semangat masyarakat Aceh yang kuat dan pantang menyerah. Pola lantainya pun bervariasi sehingga membuat tari ini lebih menarik. Hal inilah yang membuat penulis tertarik untuk mengkaji tari Ratoeh Jaroe, dengan judul penelitian "Bentuk Penyajian Tari Kreasi Ratoeh Jaroe di Sanggar Budaya Aceh Nusantara (BUANA) Banda Aceh".

\section{Metodologi Penelitian}

Penelitian ini menggunakan metode kualitatif karena melibatkan proses identifikasi historis dan observasi dalam mengumpulkan data. Proses analisis menggunakan pendekatan deskriptif agar dapat menuturkan masalah yang ada berdasarkan data-data dengan bertatap muka dan berinteraksi langsung di lapangan dengan narasumber.

\section{Hasil Penelitian dan Pembahasan}

Sanggar Budaya Aceh Nusantara (BUANA) terletak di Taman Budaya Banda Aceh dengan koordinator Khairul Anwar dan ketua Nurman Effendi. Sanggar Budaya Aceh Nusantara (BUANA) didirikan pada tanggal 19 Januari 1999 sebagai salah satu wadah kreativitas muda mudi di bidang seni dan budaya Aceh, khususnya kesenian tradisional Aceh dan kreasi. Tari yang termasuk ke dalam tari kreasi dikembangkan dari pola garapan tari tradisional Aceh. 
Tari Ratoeh Jaroe adalah tari kreasi yang bersumber dari tradisi Aceh. Tari Ratoeh Jaroe biasanya disajikan dalam perayaaan adat dan bisa juga disajikan sebagai media hiburan bagi masyarakat. Syair dalam tari Ratoeh Jaroe mengandung makna yang dalam sebagai khazanah kebudayaan Aceh. Latar belakang hadirnya tari Ratoeh Jaroe untuk membangkitkan kembali semangat masyarakat Aceh dari keterpurukan konflik/musibah yang terjadi di Aceh, serta menularkan nilai Islam dalam syair yang dibawakan.

Menurut Khairul Anwar (Koreografer BUANA) fungsi tari Ratoeh Jaroe ini bukan hanya tari tontonan untuk menghibur masyarakat namun juga berfungsi sebagai media keagamaan, kependidikan, dan kebersamaan yang disampaikan melalui syair dalam tari ini.

Tari Ratoeh Jaroe memiliki tema yang menceritakan perjalanan kehidupan masyarakat Aceh tentang segala sesuatu yang menyangkut aspek kehidupan masyarakat. Contohnya: kisah di perantauan, kisah sedih, gembira, nasihat dan membangkitkan semangat dari keterpurukan.

\section{Bentuk Penyajian Tari Ratoeh Jaroe}

Berdasarkan hasil observasi di sanggar Budaya Aceh Nusantara, proses penciptaan tari ini sama seperti proses pembuatan tari lainnya, dalam tarian ini penari bukan hanya dibekali dengan hafalan gerak dan pola lantainya saja, akan tetapi penari terlebih dulu diberikan pemahaman tentang tari tradisional dengan makna-makna yang terkandung di dalamnya, yaitu kehidupan masyarakat Aceh, terutama dalam kehidupan masyarakat Aceh masa lampau. Pada masyarakat Aceh masa kini ajaran Islam tetap dipandang sebagai nilai yang esensial dan masih sangat besar pengaruhnya sekalipun pengaruh dari budaya modern mulai besar pula. Dengan kata lain telah terjadi pergeseran antara budaya lampau dan budaya modern.

Proses penggarapan tari ini berlangsung selama lebih kurang dua bulan lima belas hari dengan tempat berlatih tari di Gedung Galeri Taman Seni Budaya Banda Aceh, Sekretariat Sanggar Budaya Aceh Nusantara (BUANA) Banda Aceh.

Gerakan-gerakan di dalam tari Ratoeh Jaroe ini terinspirasi dari beberapa jenis tari tradisional Aceh di antaranya: Ratoeh Duek, Ratep Meuseukat, Likok Puloe, Saman, Ratoeh Bantai dan lain sebagainya, kemudian diolah ke dalam bentuk seni tari baru dengan sentuhan pengembangan koreografi yang disebut dengan tari Ratoeh Jaroe. Tari ini tidak menggunakan properti atau alat-alat pertunjukan yang dapat membantu tari ini dalam pertunjukannya, baik properti yang berasal dari tata busana penari atau properti dari luar tata busana tari.

\section{Sejarah Tari Ratoeh Jaroe}

Hasil penelitian didapatkan melalui observasi, wawancara, dan dokumentasi. Dari hasil wawancara pada salah satu seniman di Aceh yaitu Khairul Anwar sebagai koreografer tari di Sanggar Budaya Aceh Nusantara (BUANA) Banda Aceh. Beliau menciptakan tari kreasi Ratoeh Jaroe ini mengikuti perkembangan zaman dan juga mengubah pola lantai serta musik menjadi suatu tarian yang lebih menarik dan dapat dinikmati oleh masyarakat luas. Maka terciptalah tari Ratoeh Jaroe di sanggar Budaya 
Aceh Nusantara (BUANA) Banda Aceh dengan kemasan tari yang berbeda dengan tarian tradisional Aceh pada umumnya.

Tari yang diberi judul Ratoeh Jaroe adalah tari yang berkembang pada era kekinian, di mana tari Ratoeh di bagian pesisir Aceh telah diramu dan diwujudkan ke dalam seni pertunjukan yang menarik, dari kemasan nilai estetika gerak/musik dan penyajiannya kini dapat dimainkan dengan konsep lebih modern, yang tidak mengesampingkan dan menghilangkan nilai-nilai tradisi di dalamnya.

Ratoeh Jaroe dapat menjadi tempat segala sesuatu yang menyangkut aspek kehidupan masyarakat, contohnya: kisah di perantauan, kisah sedih, gembira, nasihat, dan membangkitkan semangat. Ide dasar dari tari Ratoeh Jaroe ini bermula dari tari Likoek puloe yang berkembang di Aceh, karena perkembangan di Jakarta didominasi oleh tarian Rampai Aceh, maka terciptalah sebuah proses tari duduk dengan tari yang diiringi rapa' $i$ sebagai pengiringannya, sebagaimana lazimnya tari-tarian yang ada di daerah Provinsi Aceh.

Tari Ratoeh Jaroe pada sanggar Budaya Aceh Nusantara diciptakan oleh Khairul Anwar pada tahun 2008 dan nama Ratoeh Jaroe untuk pertama kalinya diberikan oleh Khairul Anwar pada tahun 2011. Gerakan-gerakan di dalam tari Ratoeh Jaroe ini terinspirasi dari beberapa jenis tari di antaranya: Ratoeh Duek, Ratep Meuseukat, Likok Puloe, Saman, Ratoeh Bantai dan lain sebagainya, dan diolah ke dalam bentuk seni tari baru dengan sentuhan pengembangan koreografi yang disebut dengan tari Ratoeh Jaroe. Tarian ini membutuhkan fisik yang kuat dikarenakan pada setiap gerakannya selalu berpindah posisi dengan gerak yang kuat.

\section{Tema Tari Ratoeh Jaroe}

Tema yang terkandung di dalam tari ini yaitu menceritakan tentang perjalanan masyarakat Aceh dari zaman penjajahan Belanda hingga penjajahan Jepang menuju kepada zaman merdeka. Dan di dalam tari ini tetap mengandung ajaran Islam, seperti yang ada pada syair berikut "Hu ayoen.. Ayoen-ayoen elallah... Salamatan-salamatan tadikeelah.. Allah.. Allah.. Allahhu Ya Allah. Hanya kepada Allah kita selalu memohon pertolongan atas keselamatan, Allah dan hanya Allah".

Berdasarkan tema tersebut terciptalah sebuah sinopsis atau pesan dan amanah yang disampaikan pada tari Ratoeh Jaroe ini. Sinopsis tari ini diuraikan sebagai berikut, "Tari Ratoeh Jaroe adalah tari yang berkembang pada era kekinian, di mana tari Ratoeh di bagian pesisir Aceh telah diramu dan diwujudkan ke dalam seni pertunjukan yang menarik, dari kemasan nilai estetika, gerak, dan musik. Penyajiannya kini dapat dimainkan dengan konsep lebih modern, yang tidak mengenyampingkan dan menghilangkan nilai-nilai tradisi di dalamnya.

\section{Jenis Tari dan Jumlah Penari Ratoeh Jaroe}

Tari Ratoeh Jaroe adalah tari kreasi yang berpolakan tradisional dan berasal dari Aceh. Tari Ratoeh Jaroe biasanya disajikan dalam perayaaan adat dan bisa juga disajikan sebagai media hiburan bagi masyarakat. Syair dalam tari Ratoeh Jaroe mengandung makna yang dalam sebagai khazanah kebudayaan Aceh. Latar belakang hadirnya tari Ratoeh Jaroe juga untuk membangkitkan kembali semangat masyarakat Aceh dari 
keterpurukan konflik/musibah yang terjadi di Aceh, serta menularkan nilai Islam dalam syair yang dibawakan.

Tari Ratoeh Jaroe ditarikan oleh sebelas orang penari wanita, yang terdiri dari dua kelompok yaitu penari merah dan penari hijau. Kedua kelompok penari merah dan hijau ini didasarkan pada kombinasi pola lantai yang berubah-ubah dan dibedakan dengan warna baju penari yang memiliki dua warna. Jumlah penarinya bisa saja berubah menurut kondisi pentas.

\section{Gerak Tari Ratoeh Jaroe}

Gerak tari Ratoeh Jaroe lebih dominan kepada gerak-gerak yang tegas dan cepat. Tari ini memperlihatkan sebuah gerakan yang menceritakan tentang bangkitnya semangat masyarakat Aceh dari keterpurukan. Tari ini memiliki dua puluh delapan gerak, enam pola lantai pada saat gerak berdiri, tiga belas pola lantai pada saat duduk, serta lima belas bentuk pengulangan yang ke semua ragam dilakukan dengan hitungan tari yang berbeda.

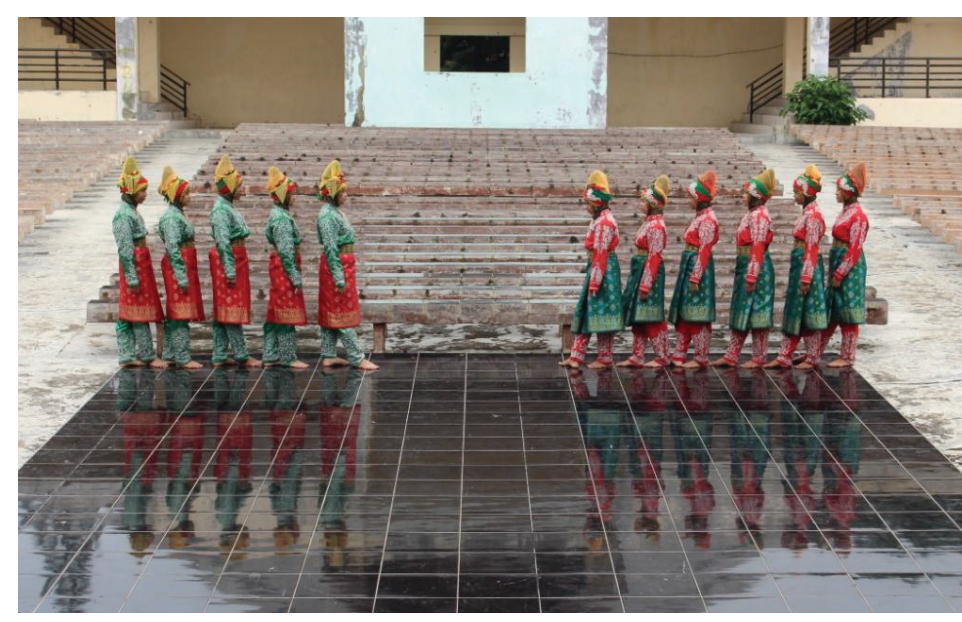

Gambar 1: Gerak Masuk pertama (Foto: Riska Gebrina, 2014)

\section{Hu ayoooeeeenn}

Ayooen-ayooen elallah...

Salamatan.. Salamatan tadikellah..

Allah Allah Allahu Ya Allah..

Maksud dari syair ini adalah hanya pujian-pujian kepada Allah sang pencipta langit dan bumi beserta isinya. 


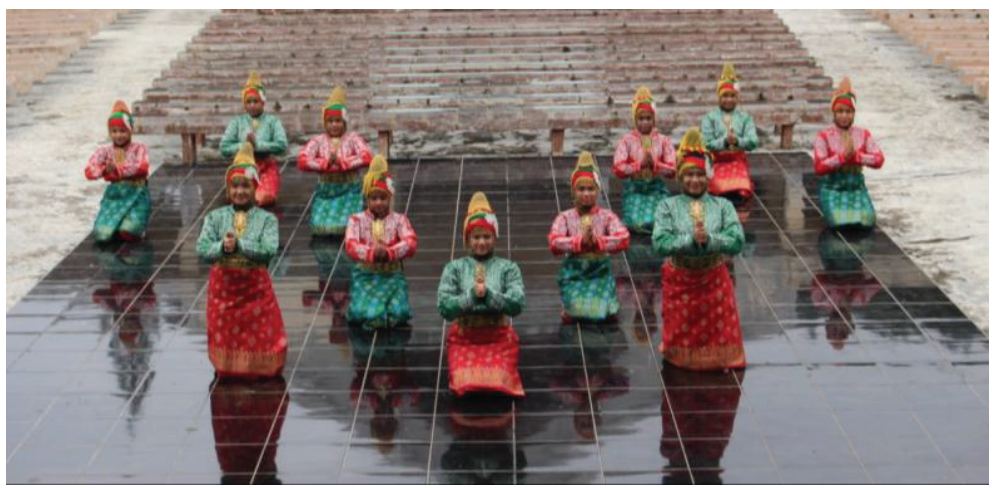

Gambar 2: Gerak Bumpempeng Ratoeh Jaroe

(Foto: Riska Gebrina, 2014)

Gerakan ini dilakukan sebanyak $1 \times 1$ $8+6$ dan gerakan ini dilakukan pada posisi duduk. Gerakan bumpempeng adalah gerak yang selalu dipakai dalam tari ini, dan gerakan ini selalu berada di awal tari dengan gerakan yang serentak.

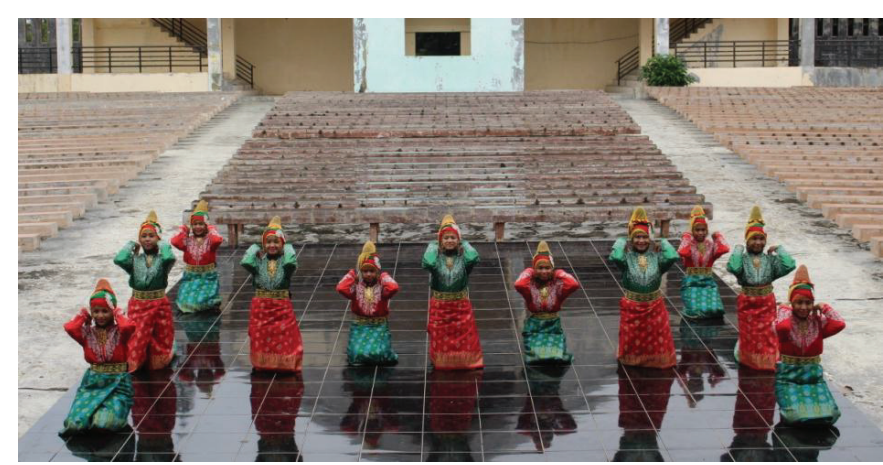

Gambar 3: Gerak Jak Ku Timang

(Foto: Riska Gebrina, 2014)

Gerak ini dilakukan dengan syair:

Jak ku timang prang, boeh gadeng-gadeng adang

Di keude bang di loen hayak bahoe

Cukoep meusigrak alahai poe

Jaroe ngoen gaki jak ku jak ku timang prang

Maksud dari syair ini adalah hanya untuk memberi semangat dan kesenangan bagi masyarakat, sama halnya seperti kebiasaan masyarakat Aceh yang selalu meuratoeh atau berbicara antarsesama masyarakat Aceh. 


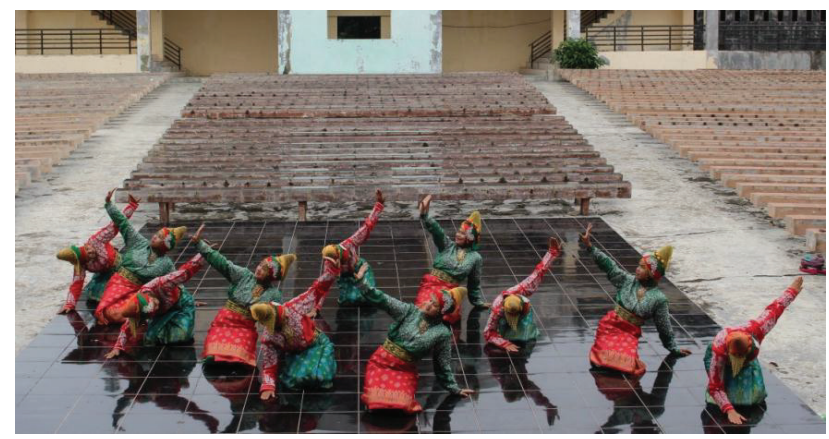

Gambar 4: Gerak Ilahoyan

(Foto: Riska Gebrina, 2014)

Gerak ini dilakukan dengan syair:

Illahoyan sayang rakan lahee lee hala

Ka kuprak hai rakan e lahee lee laha

Hai di dara.. dara Aceh meulinggak-linggak sahoe

Di keuprak jaroe ratoeh kamoe baa

Maksud dari syair ini adalah kebersamaan dan keceriaan yang dilakukan oleh masyarakat Aceh, khususnya pada aneuk dara di gampoeng atau anak gadis yang di desa. Pada syair ini jelas dikatakan bahwa walau susah mereka tetap menjalin kebersamaan yang selalu ceria tanpa adanya konflik.

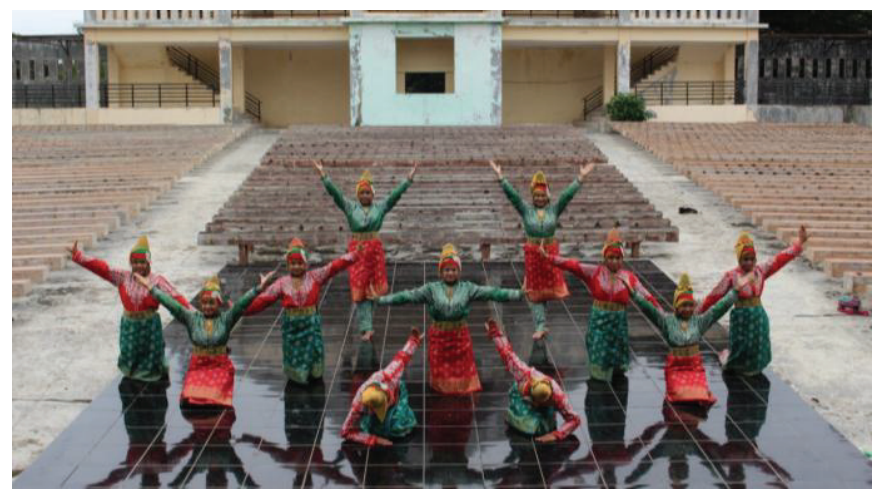

Gambar 5: Pose Akhir

(Foto: Riska Gebrina, 2014)

Pada pose akhir ini, semua penari memiliki posenya masing-masing. Berikut keterangannya. Nomor 1, digunakan oleh penari yang level sedang. Nomor 2, juga digunakan oleh penari level sedang. Nomor 3, digunakan oleh penari level rendah. Nomor 4, digunakan oleh penari level tinggi.

Tenaga yang digunakan oleh penari pada tari dapat dikatakan tegas atau kuat karena posisi yang tegak menjadi dominan dalam gerak tari dengan gerak yang patahpatah atau memiliki energi dan aksen tertentu. Tumpuan tenaga lebih banyak di wilayah 
tangan tungkai atas dengan posisi kepala yang juga banyak melakukan gerak dengan mengikuti arah tangan bergerak. Ruang yang digunakan penari dalam tari ini ada dua yaitu ruang pribadi dan ruang umum. Ruang pribadi yang dilakukan pada gerak tari ini lebih dominan kepada arah gerak yang luas dan terkadang sempit seperti posisi tangan yang terbuka atau direntangkan kiri dan bergerak pada daerah diri sendiri saja. Sedangkan ruang umum adalah arah bergerak penari dari satu tempat ke tempat yang lain. Pada tari ini penari banyak melakukan gerak dengan berpindah posisi.

Waktu dalam tari ini yang dilihat dari irama, ritme, dan tempo sesuai dengan gerak tari. Jika gerak yang dilakukan menggunakan hitungan lambat maka gerak tersebut telah disesuaikan dengan irama atau musik yang ritmenya sesuai.

\section{Kesimpulan}

Berdasarkan hasil penelitian yang telah penulis lakukan di sanggar Budaya Aceh Nusantara (BUANA) Banda Aceh, maka di sini penulis membuat beberapa kesimpulan sebagai berikut:

Tarian Ratoeh Jaroe berasal dari perkataan Aceh yaitu "Ratoeh" yang artinya Berkata atau Berbicara dan "Jaroe" yang artinya Tangan dan Jari Tangan. Secara umum Ratoeh Jaroe berarti melantunkan syair atau menceritakan sebuah kisah dengan menggunakan pergerakan jari tangan sebagai penegas.

Tarian ini pada dasarnya berfungsi untuk menyebarkan pengaruh Islam pada masyarakat melalui tutur bahasa. Tempat pertunjukan tari Ratoeh Jaroe terbaik adalah procenium stage dan tapal kuda, tetapi Ratoeh Jaroe bisa juga ditampilkan di ruang tertutup dan terbuka (lapangan).

Tari Ratoeh Jaroe sangat berkembang di seluruh Aceh maupun Indonesia, setiap sanggar memiliki keunikan dan kekhasan masing-masing pada setiap geraknya, begitu juga pada sanggar Budaya Aceh Nusantara (BUANA). Berdasarkan observasi pada sanggar Budaya Aceh Nusantara (BUANA) tari ini memiliki keunikan dari musik, gerak, dan pola lantai pada setiap pergerakannya.

Tarian ini ditarikan oleh sebelas penari wanita. Pakaian tari ini terdiri dari baju tradisional Aceh lengkap yang telah dimodifikasi dan berwarna hijau dan merah, songket Aceh, sanggul Aceh, anak jilbab, cleopatra, tile warna hijau dan merah. Iringan tari berupa alat musik tradisional Aceh, yaitu seurune kale, rapai, geundrang, dan darabbuka dengan tempo lambat di awal, sedang, dan cepat di akhir tarian. Pola lantainya cenderung lurus, diagonal, segitiga, berbentuk huruf $\mathrm{W}$, dan huruf $\mathrm{H}$.

Tari Ratoeh Jaroe memiliki 33 gerakan, yaitu: gerak masuk, gerak step dua, gerak silang kaki, gerak dayung, gerak lenggok step, gerak seudati, gerak tepuk saleum, gerak putar melayang, gerak tepuk saleum seurune, gerak memberi kasih balik, gerak tepuk silang, gerak masri ya salam, gerak kopak, gerak bumpempeng Ratoeh Jaroe, gerak bumpengbum Ratoeh Jaroe, gerak pindah hentak dada, gerak tangan buka tutup, gerak $4,2,1,1,2,1,4$, gerak angkat saleum, gerak rapai geleng, gerak patah-patah, gerak silang tangan, gerak jak ku timang, gerak ilahoyan, gerak level tinggi, gerak level rendah, gerak 
burung terbang, gerak buka lima jari, gerak pukul dada, gerak pose akhir, gerak pulang. Tata rias yang digunakan adalah rias cantik dengan warna disesuaikan dengan kostum.

\section{Kepustakaan}

Hadi, Y. Sumandiyo. 2007. Aspek-aspek Dasar Koreografer Kelompok, Jakarta: Elkapi. Hermaliza, Essi. 2011. Buletin Haba Kapita Selekta Sejarah dan Budaya, Banda Aceh: Sejarah dan Nilai Tradisional.

Khairul Anwar. Tari Ratoeh Jaroe. Banda Aceh: No Government Individual Sedyawati, Edi. 1986. Pengetahuan Elementer Tari. Jakarta.

Sugiyono. 2011. Metode Penelitian Kuantitatif Kualitatif dan R\&D. Bandung: Alfabet. www.teaterku.wordpres.com http://adi2012.wordpress.com/2013/09/21/pengetahuan-dasar-tata-riasuntukketrampilan-guruguru-seni-tari/ 18Juli2014: 13.41 http://syafriadimoak.blogspot.com/2013/12/jenis-jenis-panggung.html18Juli2014: 13.43 